\title{
Comparison of Various Foods Intakes and Their Relationships with Body Mass Index in Japanese Old Men and Women
}

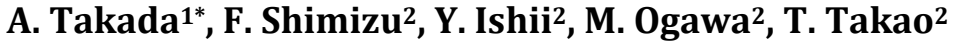 \\ ${ }^{1}$ International Projects on Food and Health (NPO), Tokyo, Japan \\ ${ }^{2}$ Faculty of Human Life and Environmental Sciences, Showa Women's University, Tokyo, Japan \\ Email: ^takada-1a@kmd.biglobe.ne.jp
}

How to cite this paper: Takada, A., Shimizu, F., Ishii, Y., Ogawa, M. and Takao, T. (2021) Comparison of Various Foods Intakes and Their Relationships with Body Mass Index in Japanese Old Men and Women. Food and Nutrition Sciences, 12, 591-601.

https://doi.org/10.4236/fns.2021.126044

Received: May 17, 2021

Accepted: June 26, 2021

Published: June 29, 2021

Copyright $\odot 2021$ by author(s) and Scientific Research Publishing Inc. This work is licensed under the Creative Commons Attribution International License (CC BY 4.0).

http://creativecommons.org/licenses/by/4.0/

\section{(c) (i) Open Access}

\begin{abstract}
Objective: Obesity is an important health problem, leading to many metabolic diseases such as type 2 diabetes mellitus, cardiovascular diseases, cancer etc. There are many diet proposals to combat obesity. Since obesity is relatively rare in Japan, we wanted to know what kinds of foods influence body mass index (BMI) in old Japanese people. Methods: Healthy participants were given self-administered diet history questionnaires and described answers on each item by recollection of diets they took (7 days dietary recall). We used a brief-type self-administered diet history questionnaire (BDHQ) by using which the Japanese Ministry of Health, Labour and Welfare reports national Nutrition Surveys. From these questionnaires, we calculated the intakes of energy, carbohydrate, fat, protein or other foods. Results: Men take more alcohol, salt fruit, beans, and eggs than women. Intakes of major foods such as carbohydrate, lipid, and protein did not influence BMI in men and women. Conclusion: Within the range of foods intakes in Japan, no restriction of any food such as carbohydrate is not necessary for staying lean.
\end{abstract}

\section{Keywords}

Carbohydrate, Protein, Fish, Glucose, Insulin, BMI (Body Mass Index), Obesity

\section{Introduction}

Obesity has been dramatically increased world-widely and to know the effective and safe weight-loss diets must be investigated [1] [2] [3].

Effects of various weight-loss diets have been proposed and compared. Low 
carbohydrate, high-protein diets were compared with very low fat, energy-restricted diets [4] [5] [6] [7].

Recently the carbohydrate-insulin model has been proposed [8]. According to this model, the hormone insulin plays dominant anabolic control. Insulin decreases the circulating major metabolic fuels by stimulating glucose uptake into tissues, inhibiting release of fatty acids from adipose tissue, so that ketones are produced in the liver, and promoting fat and glycogen deposition. Consistent with these effects, increased insulin actions (such as insulin-producing tumors, initiation of insulin treatment of type 2 diabetes or overtreatment of type 1 diabetes) are shown to be associated with weight gain. Interestingly, inadequate insulin treatment of type 1 diabetes and drugs that inhibit insulin secretion causes weight loss.

Dietary carbohydrate has the most potent effects, which vary by amount and type. Most refined grains, potato products and added sugars digest quickly and have a relatively high GI (glycemic index), whereas non-starchy vegetables, legumes, whole fruits and intact whole grains tend to have a moderate or low GI.

The Mediterranean diet was rich in vegetables and low in red meat, with poultry and fish replacing beef and lamb. Mediterranean and low-carbohydrate diets were shown to be effective alternatives to the low-fat diet for weight loss and appear to be just as safe as the low-fat diet [9].

As stated later, the rate of obese people is very low, in fact, one of OECD countries with the lowest obesity rate [10]. We have previously reported correlations between various foods intakes, plasma levels of amino acids or fatty acids in Japanese young and old men and women [11] [12] [13] [14]. So it may be interesting to know what kinds of foods old Japanese men and women are taking and whether any kind of foods intake influences body mass index.

In the present article, we report various foods intakes and their relationships to BMI in old Japanese men and women.

\section{Method}

We asked male and female acquaintances older than 50 years old. Acquaintances mean that these participants are personal friends of our group members. The sample sizes and ages of participants are as follows. Acquaintances are older than 50 years old; men $(\mathrm{n}=44$, age; $70.07 \pm 11.1)$ and women $(\mathrm{n}=39$, age; $67.4 \pm 7.5)$. We did not ask premenopausal women to participate since data may be variable due to their hormonal influences so that sample sizes must be big to get statistically significant results. Dr. K. Matsuoka and K. Kato, who are internists, checked their health carefully and examined their blood samples then recruited them if there were no health problems such as diabetes, hypertension or not serious diseases experienced in the past. They did not smoke in the past. We also excluded people who took drugs for dysli- 
pidemia, hyperglycemia, or hypertension. We collected blood samples early morning. Healthy participants were given self-administered diet history questionnaires and described answers on each item by recollection of diets they took (7 days dietary recall). We used a brief-type self-administered diet history questionnaire (BDHQ) by using which the Japanese Ministry of Health, Labour and Welfare reports national Nutrition Surveys. From these questionnaires, we calculated the intakes of energy, carbohydrate, fat, protein or other foods.

\section{Statistics}

The results are presented as means \pm SEM. Statistical significance of the differences between groups was calculated according to one-way ANOVA. When ANOVA indicated a significant difference $(\mathrm{p}<0.05)$, the mean values were compared using Tukey's least significant difference test at $p<0.05$. Spearman's correlation tests were used to examine statistical significance.

\section{Results}

Table 1 shows that height, weight and BMI (body mass index) are larger in men than women.

Table 2 shows the amounts of foods intakes of men and women.

The amounts of energy intake are larger in men than women. The amounts of intakes of protein, carbohydrate, lipid fatty acids or other foods are not different between men and women.

The amounts of intakes of alcohol, salt, sucrose, beans, beverages and seasonings are higher in men than women. Since people take salty cakes, beans when they take alcohol or beverages such as Sake in Japan, such habits influence men's foods intakes.

Table 3 shows a correlation between foods and BMI. There is no correlation between any food intake and BMI in women. There are correlations between intakes of vegetable lipid, $\mathrm{n}-6$ fatty acid, fruits and eggs and BMI in men.

Figure 1 shows Scatter plots and regression line between intakes of carbohydrate and BMI in men and women.

Figures 1-3 show there is no correlation between intakes of carbohydrate, lipid and protein and BMI.

Table 1. Basic characteristics of participants.

\begin{tabular}{|c|c|c|c|c|}
\hline & & $\begin{array}{l}\text { Old men } \\
\mathrm{n}=44\end{array}$ & $\begin{array}{l}\text { Old women } \\
\qquad \mathrm{n}=39\end{array}$ & Significance \\
\hline Age & & $70.7 \pm 11.1$ & $67.4 \pm 7.5$ & \\
\hline Height & $\mathrm{cm}$ & $166.5 \pm 6.6$ & $157.1 \pm 5.8$ & ** \\
\hline Weight & $\mathrm{kg}$ & $67.4 \pm 11.1$ & $50.6 \pm 6.8$ & $* *$ \\
\hline BMI & $\mathrm{kg} / \mathrm{m}^{2}$ & $24.3 \pm 3.3$ & $20.5 \pm 2.5$ & $* *$ \\
\hline
\end{tabular}

${ }^{* *} \mathrm{p}<0.01$ (old men vs. old women). 
Table 2. The amounts of various foods intakes.

\begin{tabular}{|c|c|c|c|c|}
\hline \multicolumn{2}{|c|}{ Foods intakes of men and women } & \multirow{2}{*}{ Old men $\mathrm{n}=44$} & \multirow{2}{*}{ Old women $\mathrm{n}=39$} & \multirow{2}{*}{ Significance } \\
\hline Foods & Per day & & & \\
\hline Energy & $\mathrm{kcal} / \mathrm{d}$ & $2265 \pm 621$ & $1941 \pm 535$ & * \\
\hline Protein & $\mathrm{g} / \mathrm{d}$ & $86.2 \pm 27.7$ & $80.0 \pm 27.3$ & \\
\hline Animal protein & $\mathrm{g} / \mathrm{d}$ & $51.8 \pm 22.0$ & $47.4 \pm 19.8$ & \\
\hline Vegetable protein & $\mathrm{g} / \mathrm{d}$ & $34.4 \pm 9.9$ & $32.6 \pm 10.9$ & \\
\hline Lipid & $\mathrm{g} / \mathrm{d}$ & $66.4 \pm 20.6$ & $60.9 \pm 20.9$ & \\
\hline Animal lipid & $\mathrm{g} / \mathrm{d}$ & $32.2 \pm 13.4$ & $29.0 \pm 10.7$ & \\
\hline Vegetable lipid & $\mathrm{g} / \mathrm{d}$ & $34.2 \pm 9.9$ & $31.9 \pm 11.9$ & \\
\hline Carbohydrate & $\mathrm{g} / \mathrm{d}$ & $276.0 \pm 89.4$ & $248.2 \pm 76.9$ & \\
\hline Saturated aftty acid & $\mathrm{g} / \mathrm{d}$ & $17.7 \pm 6.5$ & $16.3 \pm 5.6$ & \\
\hline Monosaturated fatty acid & $\mathrm{g} / \mathrm{d}$ & $24.2 \pm 7.6$ & $21.6 \pm 7.7$ & \\
\hline Polysaturated fatty acid & $\mathrm{g} / \mathrm{d}$ & $15.6 \pm 4.7$ & $14.6 \pm 5.3$ & \\
\hline Cholesterol & $\mathrm{mg} / \mathrm{d}$ & $469.9 \pm 183.2$ & $440.4 \pm 187.9$ & \\
\hline Soluble dietary fiber & $\mathrm{g} / \mathrm{d}$ & $3.8 \pm 1.4$ & $4.0 \pm 1.5$ & \\
\hline Insoluble dietary fiber & $\mathrm{g} / \mathrm{d}$ & $11.2 \pm 4.9$ & $11.0 \pm 4.1$ & \\
\hline Total dietary fiber & $\mathrm{g} / \mathrm{d}$ & $15.5 \pm 5.7$ & $15.3 \pm 5.7$ & \\
\hline Salt & $\mathrm{g} / \mathrm{d}$ & $13.9 \pm 4.2$ & $11.5 \pm 3.2$ & ** \\
\hline Sugar & $\mathrm{g} / \mathrm{d}$ & $17.8 \pm 10.9$ & $15.1 \pm 8.5$ & \\
\hline Alcohol & $\mathrm{g} / \mathrm{d}$ & $28.0 \pm 28.6$ & $9.7 \pm 16.5$ & ** \\
\hline$n-3$ fatty acid & $\mathrm{g} / \mathrm{d}$ & $3.4 \pm 1.3$ & $3.1 \pm 1.4$ & \\
\hline $\mathrm{n}-6$ fatty acid & $\mathrm{g} / \mathrm{d}$ & $12.2 \pm 3.6$ & $11.4 \pm 4.0$ & \\
\hline Grains & $\mathrm{g} / \mathrm{d}$ & $412.1 \pm 165.8$ & $338.6 \pm 171.6$ & \\
\hline Potatoes & $\mathrm{g} / \mathrm{d}$ & $63.4 \pm 46.1$ & $53.2 \pm 41.3$ & \\
\hline Sucrose & $\mathrm{g} / \mathrm{d}$ & $7.5 \pm 5.8$ & $5.1 \pm 2.9$ & * \\
\hline Beans & $\mathrm{g} / \mathrm{d}$ & $59.0 \pm 43.2$ & $82.5 \pm 59.3$ & * \\
\hline Green and yellow vegetables & $\mathrm{g} / \mathrm{d}$ & $148.0 \pm 91.1$ & $145.4 \pm 75.7$ & \\
\hline Other vegetables & $\mathrm{g} / \mathrm{d}$ & $222.9 \pm 106.7$ & $220.1 \pm 117.5$ & \\
\hline Fruits & $\mathrm{g} / \mathrm{d}$ & $159.1 \pm 156.1$ & $212.8 \pm 115.9$ & \\
\hline Fish & $\mathrm{g} / \mathrm{d}$ & $106.4 \pm 63.6$ & $94.0 \pm 61.7$ & \\
\hline Eggs & $\mathrm{g} / \mathrm{d}$ & $45.3 \pm 31.9$ & $41.9 \pm 27.1$ & \\
\hline Milk & $\mathrm{g} / \mathrm{d}$ & $154.3 \pm 125.1$ & $169.7 \pm 105.1$ & \\
\hline Oils & $\mathrm{g} / \mathrm{d}$ & $12.8 \pm 5.6$ & $11.1 \pm 5.8$ & \\
\hline Cookies & $\mathrm{g} / \mathrm{d}$ & $57.7 \pm 45.1$ & $62.1 \pm 43.1$ & \\
\hline Beverages & $\mathrm{g} / \mathrm{d}$ & $1043.9 \pm 418.2$ & $779.7 \pm 429.9$ & $* *$ \\
\hline Seasonings, spices & $\mathrm{g} / \mathrm{d}$ & $296.5 \pm 163.9$ & $222.0 \pm 140.7$ & * \\
\hline
\end{tabular}

${ }^{* *} \mathrm{p}<0.01,{ }^{*} \mathrm{p}<0.05$. 
Table 3. Correlations between various foods intakes and BMI.

\begin{tabular}{|c|c|c|}
\hline Correlations & & \\
\hline BMI vs. foods & Old men $\mathrm{n}=44$ & Old women $\mathrm{n}=39$ \\
\hline Energy & 0.072 & 0.125 \\
\hline Protein & 0.050 & 0.158 \\
\hline Animal protein & 0.000 & 0.125 \\
\hline Vegetable protein & 0.144 & 0.168 \\
\hline Lipid & 0.220 & 0.157 \\
\hline Animal lipid & 0.091 & 0.066 \\
\hline Vegetable lipid & $0.335^{\star}$ & 0.216 \\
\hline Carbohydrate & 0.055 & 0.073 \\
\hline Saturated fatty acid & 0.108 & 0.145 \\
\hline Monounsaturated fatty acid & 0.279 & 0.152 \\
\hline Polyunsaturated fatty acid & 0.255 & 0.190 \\
\hline Cholesterol & 0.228 & -0.009 \\
\hline Soluble dietary fiber & 0.204 & 0.080 \\
\hline Insoluble dietary fiber & 0.222 & 0.161 \\
\hline Total dietary fiber & 0.236 & 0.136 \\
\hline Salt & 0.103 & 0.203 \\
\hline Sucrose & 0.031 & 0.022 \\
\hline Alcohol & -0.084 & -0.024 \\
\hline $\mathrm{n}-3$ fatty acid & 0.102 & 0.196 \\
\hline$n-6$ fatty acid & $0.298^{*}$ & 0.181 \\
\hline Grains & -0.052 & -0.009 \\
\hline Potatoes & -0.030 & -0.047 \\
\hline Sucrose & -0.237 & -0.037 \\
\hline Beans & -0.061 & 0.289 \\
\hline Green yellow vegetables & 0.174 & 0.095 \\
\hline Other vegetables & 0.230 & 0.248 \\
\hline Fruits & $0.298^{\star}$ & -0.047 \\
\hline Fish & -0.095 & 0.105 \\
\hline Meats & 0.142 & 0.125 \\
\hline Eggs & $0.367^{\star}$ & -0.260 \\
\hline Milk & -0.255 & 0.082 \\
\hline Oil & 0.257 & 0.258 \\
\hline Cakes & 0.203 & 0.068 \\
\hline Beverages & -0.009 & 0.130 \\
\hline Seasonings, spices & 0.012 & 0.023 \\
\hline
\end{tabular}

${ }^{*} \mathrm{p}<0.05$. 


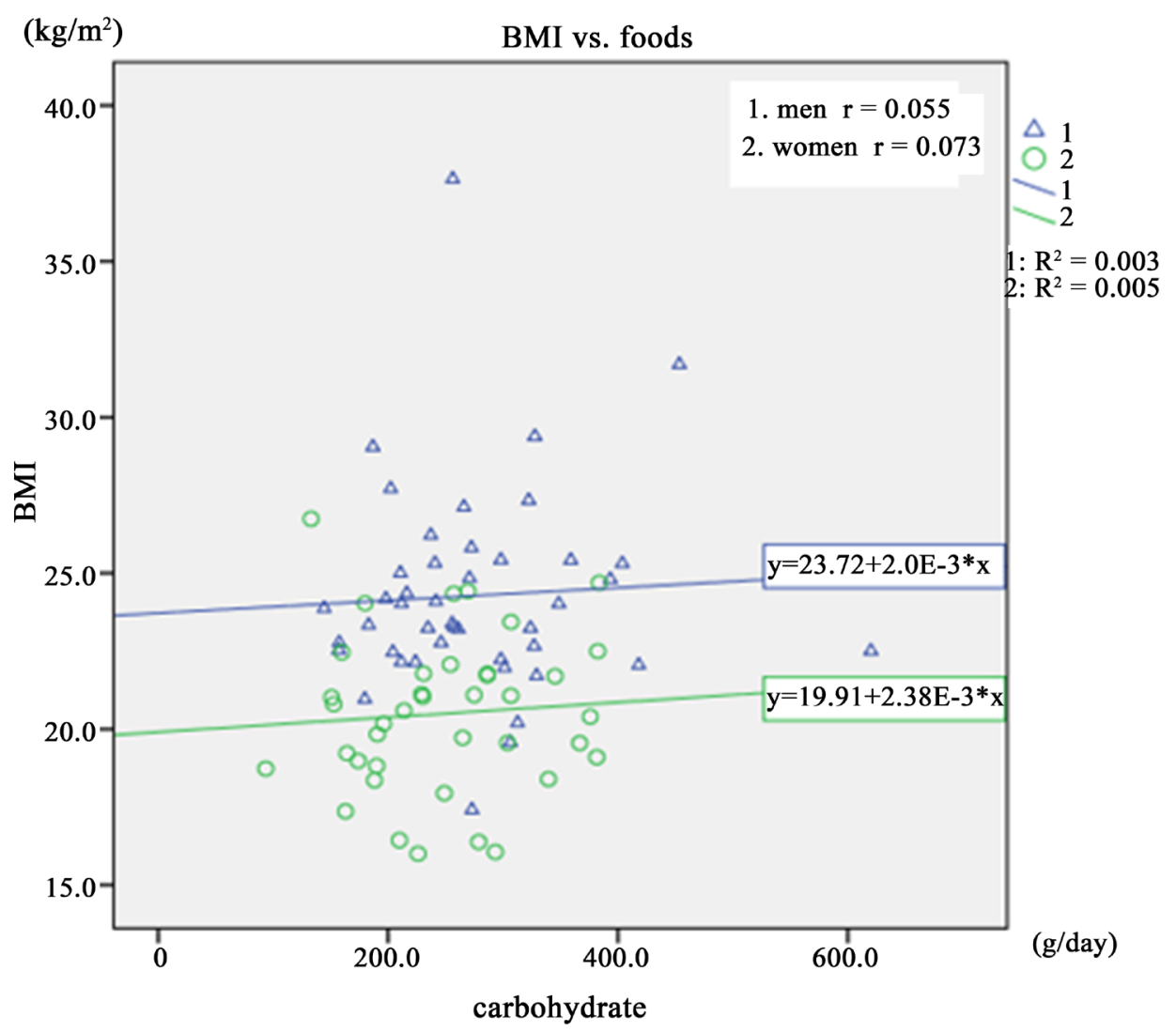

Figure 1. Scatter plots and regression lines of BMI vs. carbohydrate.

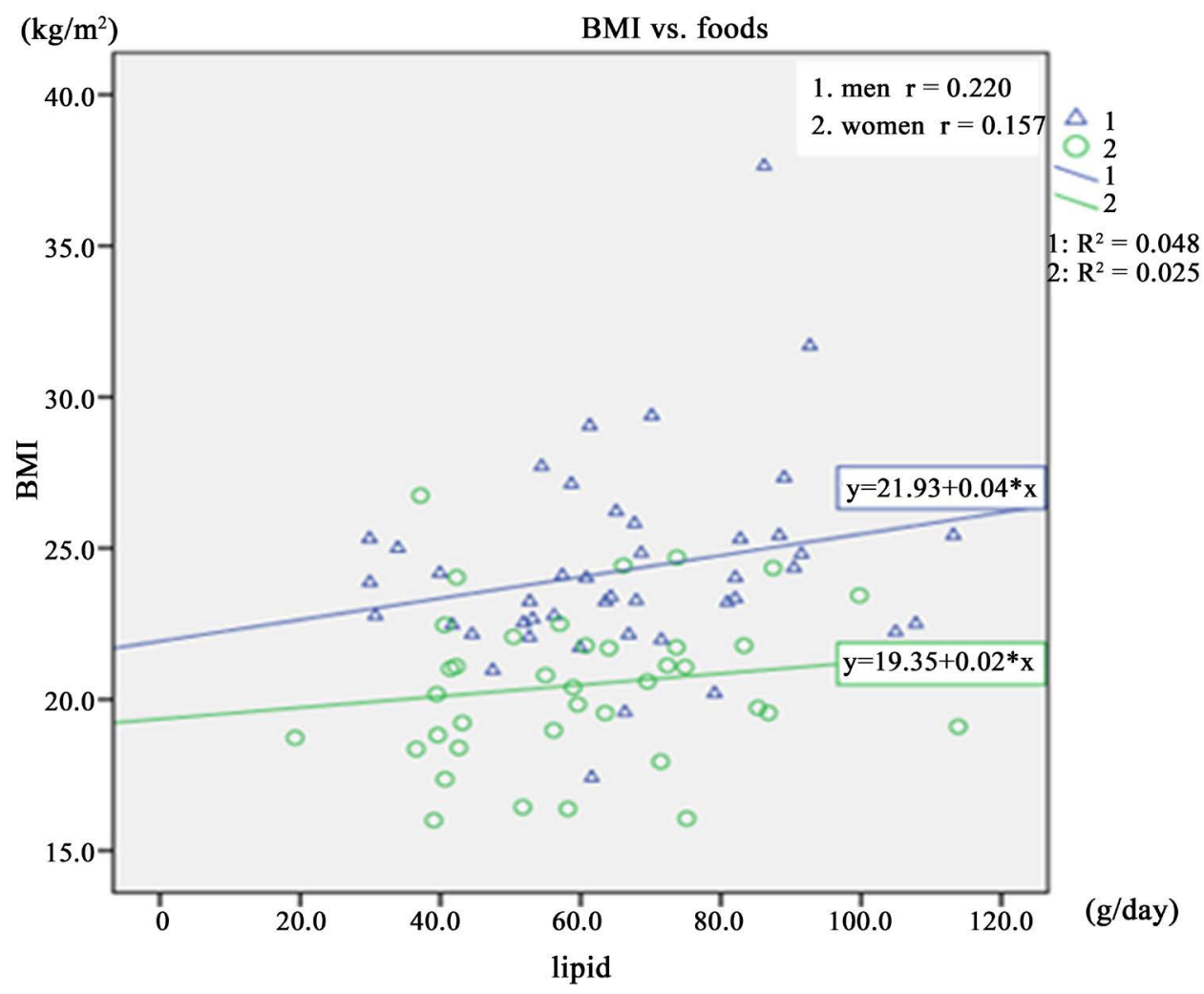

Figure 2. Scatter plots and regression lines between intakes of lipid and BMI. 


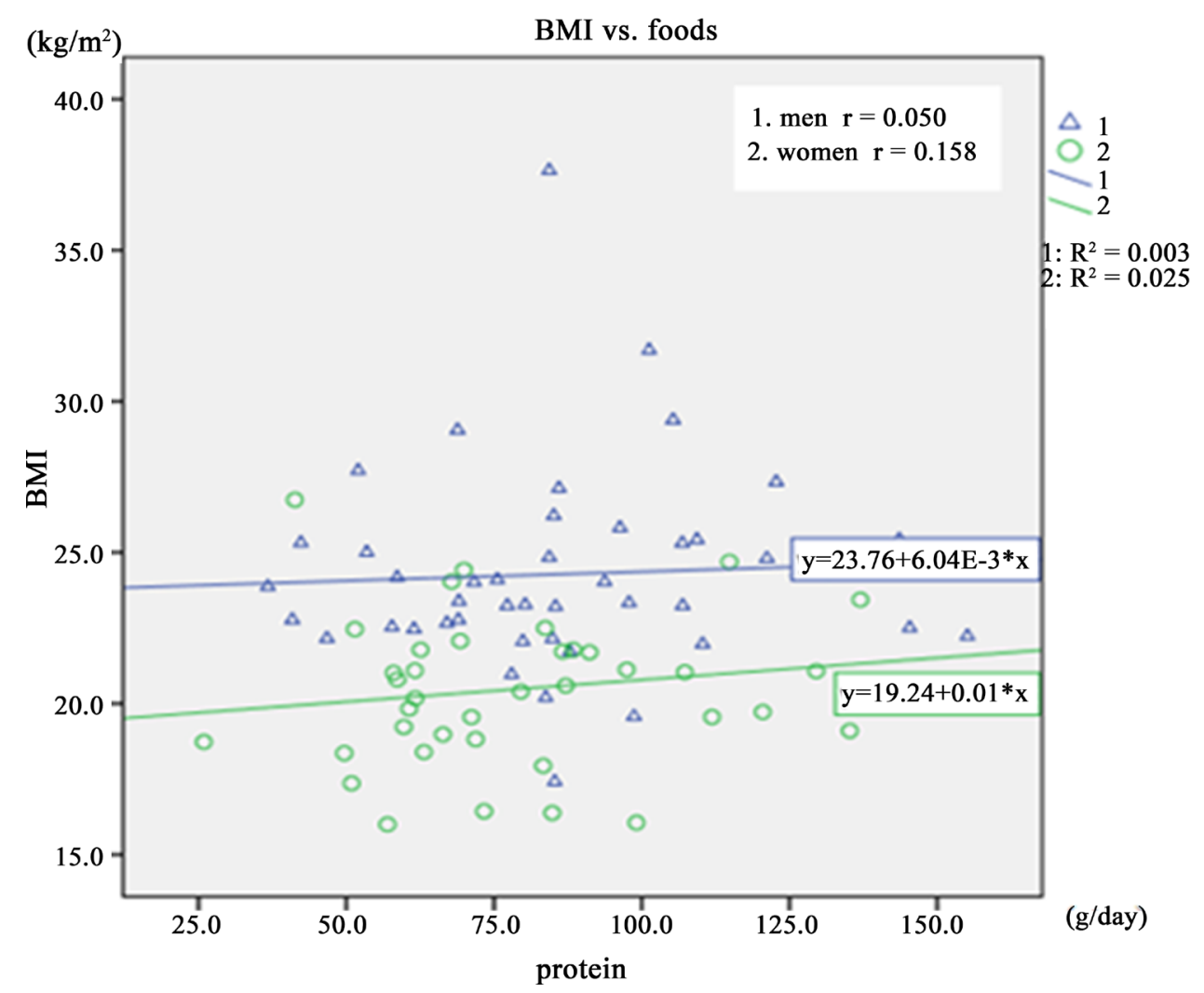

Figure 3. Scatter plots and regression lines between intakes of protein and BMI.

\section{Discussion}

It has been recognized that a global epidemic of obesity is a threat of health and functional independence of future cohorts of older adults. The obesity and age-related elevation of metabolic risks contribute physical limitation and chronic cardiometabolic disorders.

There have been many diet plans proposed to reduce body weights.

Low-carbohydrate, high-protein, high-fat diets, so called low-carbohydrate diet, have been compared with low fat energy-restricted diets [4] [5] [6] [7].

Mediterranean diet with a moderate amount of fat and a high proportion of monosaturated fat has been shown a benefit for cardiovascular diseases [9] [14] [15].

Recently, carbohydrate insulin model has been proposed [8]. According to a conventional model, overeating results in increase energy intake, which increases levels of circulating metabolic fuels such as glucose or lipids, resulting in fat storage.

According to a carbohydrate insulin model, dietary carbohydrates or other dietary and non-dietary exposure result in increased secretion of insulin. Since insulin increase uptake of glucose into adipose tissues, fat is stored. These changes cause circulating metabolic fuels. These changes cause fat deposit and obesity.

It is now well known that obesity rates are different among countries. In high-income countries, obesity rate (body mass index greater than or equal to 30 
$\mathrm{kg} / \mathrm{m}^{2}$ ) is highest among the poor, while overweight (body mass index greater than or equal to $25 \mathrm{~kg} / \mathrm{m}^{2}$ ) is shown across all wealth groups. In contrast, in low-income countries, the prevalence of overweight and obesity is higher among rich people than among poorer people [16].

Since 1975, the prevalence of overweight (body mass index (BMI) greater than or equal to $25 \mathrm{~kg} / \mathrm{m}^{2}$ ) among adults increased from $21.5 \%$ to $38.9 \%$ in 2016 [17]. Over this period, no country has shown decline in the prevalence of overweight or obesity [18]. In 2000, the World Health Organization declared obesity a pandemic and 12 years later issued a global action plan to combat its rise [19] [20]. The rapid increase in overweight and no availability of population-level control measures are considered to be important reasons of the rising disease burden and mortality from cardiovascular disease, cancer, and diabetes. Overweight and obesity do not display a consistent wealth gradient across different levels of economic development. In most low- and middle-income countries, the prevalence of overweight and obesity is higher among wealthier individuals than among poorer. However, as national economic levels increase, the burden of overweight and obesity shifts to populations with lower personal wealth [21] [22] [23].

Japan is one of the most affluent countries in the world. According to many proposal that people in the affluent countries are obese because they eat so called junk foods often.

As shown in Figure 4, men and women in Japan are the leanest in the world. People in other affluent countries such as USA are far more obese than Japanese.

In the present research, we asked healthy Japanese old men and women to report their food intakes. As shown in Table 3 and Figures 1-3, BMI levels did not change upon changes of intakes of carbohydrate, lipid and protein. These

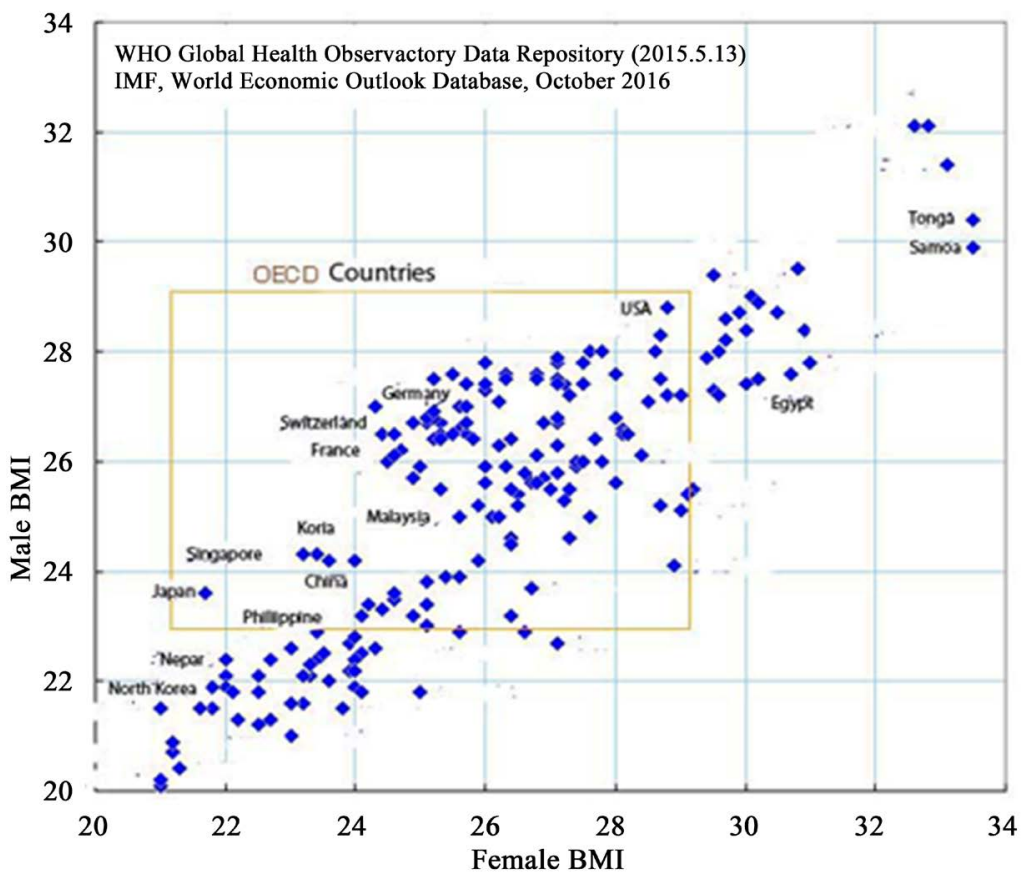

Figure 4. BMI of people in different countries. 
results suggest that within the range of intakes of foods $n$ Japan, any kinds of foods led to obesity or slimness.

It is very difficult to explain the reason why such results are obtained. Probably Japanese are very, very health concerned and try to pay much attention to foods.

Finally, some eating habits typical in Japan are discussed. Japanese tend to avoid to eat anything sweat. People think that sweat foods contain sucrose, which has been reported repeatedly unhealthy. There is o custom to eat desserts such as pie after the meal. People prefer to drink black coffee and many beverages are advertised to be sugar free. Even beer or soft drinks are advertised to be sugar free.

Japanese people are very health concerned. People often measure body weights and try to keep slender.

Recently, eating meat or foods of low carbohydrate are considered to be healthy and do not increase body weight.

People also try to be slender by increase exercise such as running, swimming, or oriental ways of exercise such as yoga.

All together Japanese ways of living seem good for weight control, thus keeping lean.

\section{Conclusion}

Foods intakes and correlations between BMI (body mass index) and various foods intakes in old Japanese men and women were examined. Changes in the amounts of various foods intakes such as carbohydrates, protein, and lipid did not affect BMI.

\section{Ethics}

This work has been approved by the Ethical committees of Showa Women's University and NPO (non-profit organization) "International projects on food and health" and has been carried out in accordance with the Code of Ethics of the World Medical Association (Declaration of Helsinki) for experiments.

\section{Acknowledgements}

Experiments were designed and performed by all of the authors. AT wrote a manuscript. Statistical analyses were done by FS. All authors read the manuscript and approved the final version. All the authors had responsibilities for the final content. AT is a chairman of NPO "International Projects on Food and Health". The NPO is financially supported by people who agreed with the purpose of the organization and voluntarily donated for the project.

\section{Financial Support}

This study was supported by grants by NPO "International Projects on Food and Health. 


\section{Conflicts of Interest}

Since no profit is obtained by the present research, there are no conflicts of interest, thus no conflicts of interest for any author.

\section{References}

[1] WHO (2000) Obesity: Preventing and Managing the Global Epidemic: Report of a WHO Consultation. World Health Organization Technical Report Series 894, 1-253.

[2] Kuczmarski, R.J., Flegal, K.M., Campbell, S.M. and Johnson, C.L. (1994) Increasing Prevalence of Overweight among US Adults: The National Health and Nutrition Examination Surveys, 1960 to 1991. JAMA, 272, 205-211. https://doi.org/10.1001/jama.1994.03520030047027

[3] Poirier, P., Giles, T.D., Bray, G.A., et al. (2006) Obesity and Cardiovascular Disease: Pathophysiology, Evaluation, and Effect of Weight Loss: An Update of the 1997 American Heart Association Scientific Statement on Obesity and Heart Disease from the Obesity Committee of the Council on Nutrition, Physical Activity, and Metabolism. Circulation, 113, 898-918. https://doi.org/10.1161/CIRCULATIONAHA.106.171016

[4] Gardner, C.D., Kiazand, A., Alhassan, S., et al. (2007) Comparison of the Atkins, Zone, Ornish, and Learn Diets for Change in Weight and Related Risk Factors among Overweight Premenopausal Women: The A to Z Weight Loss Study: A Randomized Trial. JAMA, 297, 969-977. https://doi.org/10.1001/jama.297.9.969

[5] Brehm, B.J., Seeley, R.J., Daniels, S.R. and D'Alessio, D.A. (2003) A Randomized Trial Comparing a Very Low Carbohydrate Diet and a Calorie-Restricted Low Fat Diet on Body Weight and Cardiovascular Risk Factors in Healthy Women. The Journal of Clinical Endocrinology and Metabolism, 88, 1617-1623. https://doi.org/10.1210/jc.2002-021480

[6] Foster, G.D., Wyatt, H.R., Hill, J.O., et al. (2003) A Randomized Trial of a Low-Carbohydrate Diet for Obesity. The New England Journal of Medicine, 348, 2082-2090. https://doi.org/10.1056/NEJMoa022207

[7] Stern, L., Iqbal, N., Seshadri, P., et al. (2004) The Effects of Low-Carbohydrate Versus Conventional Weight Loss Diets in Severely Obese Adults: One-Year Follow-Up of a Randomized Trial. Annals of Internal Medicine, 140, 778-785. https://doi.org/10.7326/0003-4819-140-10-200405180-00007

[8] Ludwig, D.S. and Ebbeling, C.B. (2018) The Carbohydrate-Insulin Model of Obesity: Beyond “Calories In, Calories Out”. JAMA Internal Medicine, 178, 1098-1103. https://doi.org/10.1001/jamainternmed.2018.2933

[9] Shai, I., Schwarzfuchs, D., Henkin, Y., Shahar, D.R., Witkow, S., Greenberg, I., Golan, R., Fraser, D., Bolotin, A., Vardi, H., Tangi-Rozental, O., Zuk-Ramot, R., Sarusi, B., Brickner, D., Schwartz, Z., Sheiner, E., Marko, R., Katorza, E., Thiery, J., Fiedler, G.M., Blüher, M., Stumvoll, M. and Stampfer, M.J. (2008) Weight Loss with a Low-Carbohydrate, Mediterranean, or Low-Fat Diet. The New England Journal of Medicine, 359, 229-241. https://doi.org/10.1056/NEJMoa0708681

[10] WHO (2016) Global Health Observatory Data Repository (2015, 5.15), IMF World Economic Outlook Database, October.

[11] Shimizu, F., Ogawa, M., Takao, T., Ishii, Y. and Takada, A. (2016) Correlations among Various Foods Uptakes and Body Mass Index (BMI) or Plasma Parameters. Obesity: Open Access, 2, 1-4. https://doi.org/10.16966/2380-5528.123 
[12] Ishii, Y., Shimizu, F., Ogawa, M., Takao, T. and Takada, A. (2016) Gender Differences in Foods Uptakes, Glycemic Index, BMI, and Various Plasma Parameters between Young Men and Women in Japan. Integrated Foods, Nutrition and Metabolism, 3, 427-430. https://doi.org/10.15761/IFNM.1000163

[13] Shimizu, F., Ishii, Y., Ogawa, M., Takao, T., Matsuoka, K., Kato, K. and Takada, A. (2017) Relationship between Various Food Uptakes and Body Mass Index (BMI) in Japanese Young and Old Men and Women. Journal of Clinical Nutrition \& Dietetics, 3, 2.

[14] Shimizu, F., Ishii, Y., Ogawa, M., Takao, T., Matsuoka, K., Kato, K. and Takada, A. (2017) Age and Gender Influence Differently on Various Foods Intakes, Body Mass Index (BMI), and Levels of Various Plasma Parameters in Young and Old Men and Women in Japan. Obesity: Open Access, 3, 1-7.

[15] Covas, M.I., Nyyssönen, K., Poulsen, H.E., et al. (2006) The Effect of Polyphenols in Olive Oil on Heart Disease Risk Factors: A Randomized Trial. Annals of Internal Medicine, 145, 333-341. https://doi.org/10.7326/0003-4819-145-5-200609050-00006

[16] Templin, T., Cravo Oliveira Hashiguchi, T., Thomson, B., Dieleman, J. and Bendavid, E. (2019) The Overweight and Obesity Transition from the Wealthy to the Poor in Low- and Middle-Income Countries: A Survey of Household Data from 103 Countries. PLOS Medicine, 16, e1002968. https://doi.org/10.1371/journal.pmed.1002968

[17] Collaboration (NCD-RisC) (2017) Worldwide Trends in Body-Mass Index, Underweight, Overweight, and Obesity from 1975 to 2016: A Pooled Analysis of 2416 Population-Based Measurement Studies in 128.9 Million Children, Adolescents, and Adults. The Lancet, 390, 2627-2642.

[18] Roberto, C.A., Swinburn, B., Hawkes, C., Huang, T.T., Costa, S.A., Ashe, M., Zwicker, L., Cawley, J.H. and Brownell, K.D. (2015) Patchy Progress on Obesity Prevention: Emerging Examples, Entrenched Barriers, and New Thinking. The Lancet, 385, 2400-2409. https://doi.org/10.1016/S0140-6736(14)61744-X

[19] World Health Organization (2012) A Comprehensive Global Monitoring Framework Including Indicators and a Set of Voluntary Global Targets for the Prevention and Control of Noncommunicable Diseases. World Health Organization, Geneva.

[20] Chang, A.Y., Riumallo-Herl, C., Salomon, J.A., Resch, S.C., Brenzel, L. and Verguet, S. (2018) Estimating the Distribution of Morbidity and Mortality of Childhood Diarrhea, Measles, and Pneumonia by Wealth Group in Low- and Middle-Income Countries. BMC Medicine, 16, 102. https://doi.org/10.1186/s12916-018-1074-y

[21] Dinsa, G.D., Goryakin, Y., Fumagalli, E. and Suhrcke, M. (2012) Obesity and Socioeconomic Status in Developing Countries: A Systematic Review. Obesity Reviews, 13, 1067-1079. https://doi.org/10.1111/j.1467-789X.2012.01017.x

[22] Deuchert, E., Cabus, S. and Tafreschi, D. (2014) A Short Note on Economic Development and Socioeconomic Inequality in Female Body Weight. Health Economics, 23, 861-869. https://doi.org/10.1002/hec.2968

[23] Goryakin, Y., Lobstein, T., James, W.P. and Suhrcke, M. (2015) The Impact of Economic, Political and Social Globalization on Overweight and Obesity in the 56 Low and Middle Income Countries. Social Science \& Medicine, 133, 67-76. https://doi.org/10.1016/j.socscimed.2015.03.030 